\title{
KAJIAN TERHADAP SISTEM PEMERINTAHAN DAN PRAKTEKNYA MENURUT UNDANG-UNDANG DASAR TAHUN 1945
}

\author{
Oleh : Rosdalina ${ }^{1}$
}

\begin{abstract}
Abstrak
Sistem pemerintahan Indonesia didasarkan pada dua hal yaitu sistem pemerintahan sebelum amandemen dan sistem pemerintahan setelah amandemen Undang-Undang Dasar 1945. Praktik sistem pemerintahan Indonesia mengalami beberapa variasi. Pada bulan Oktober 1945 sampai sebelum Dekrit Presiden 5 Juli 1959 telah berlaku Sistem Pemerintahan Parlementer. Dimana dapat difahami bahwa dalam konstitusi Negara kita tidak dikenal Sistem tersebut namun secara praktiknya menyimpang dari amanat konstitusi.

Dalam tulisan ini penulis mengangkat permasalahan yaitu apakah sistem pemerintahan Indonesia dalam pelaksanaannya sudah sesuai dengan UUD 1945. Dalam menjawab permasalahan di atas penulis melakukan kajian pustaka/ teoritis dalam beberapa literatur, baik dalam bentuk kajian terhadap UndangUndang Dasar 1945 sebelum dan sesudah amandemen, literatur yang terkait dan juga pada beberapa jurnal ilmiah. Kemudian dari kajian tersebut dianalisis secara yuridis normatif.

Inkonsistensi penerapan Sistem Pemerintahan ini merupakan bentuk penyimpangan terhadap ketentuan UUD 1945. Keinkonsistensian penerapan Sistem Pemerintahan tersebut didasari atas konvensi ketatanegaraan dan hukum kebiasaan yang telah diterapkan sebelumnya. Disamping itu juga dapat dikatakan karena UUD 1945 sendiri memang dimaksudkan hanya sebagai revolutie -grondwet atau undang-undang dasar kilat (ucapan Bung Karno dalam sidang BPUPKI) yaitu undang-undang dasar yang hanya dimaksudkan sebagai naskah konstitusi untuk sementara waktu dalam rangka persiapan Indonesia menjadi Negara yang merdeka dan berdaulat.

Setelah UUD 1945 mengalami empat kali perubahan yaitu dari tahun 1999, 2000, 2001 dan 2002 praktik Sistem Pemerintahan kita berlaku Sistem Pemerintahan Presidensial. Sistem ini menganut prinsip Separation of power (pemisahan kekuasaan) terhadap masing-masing lembaga Negara. Praktik sistem pemerintahan setelah amandemen ini belum sepenuhnya menganut sistem pemerintahan Presidensial murni dimana antara Presiden dan DPR masih memiliki hubungan yang sangat erat disamping sebagai fungsi pengawasan.
\end{abstract}

Kata kunci : Sistem, Pemerintahan, Amandemen

\footnotetext{
${ }^{1}$ Penulis adalah salah satu Dosen di Jurusan Syari'ah STAIN Manado
} 


\section{A. Pendahuluan}

Indonesia merupakan negara hukum sebagaimana yang tertuang dalam Pasal 1 ayat (3) Undang-Undang Dasar Tahun 1945 yang berbunyi bahwa Negara Indonesia adalah Negara Hukum. ${ }^{2}$ Konsep tentang Negara hukum ini berarti bahwa segala aspek pemerintahan harus berdasarkan dengan kontitusi negara yaitu UUD 1945. Pemerintah dalam menjalankan tugas dan kewenangannya terikat dengan aturan yang termuat dalam konstitusi tersebut. Dalam arti bahwa seluruh lembaga negara dalam hal ini Badan Pemeriksa Keuangan (BPK), Presiden, Dewan Perwakilan Rakyat (DPR), Majelis Perwakilan Rakyat (MPR), Dewan Perwakilan Daerah (DPD), Mahkamah Agung (MA), Mahkamah Konstitusi (MK), dan Komisi Yudidsial (KY) menjalankan tugas pokok dan fungsinya (Tupoksi) berdasarkan UUD 1945.

Rumusan pasal di atas sejalan dengan pandangan Plato bahwa penyelenggaraan pemerintahan yang baik adalah yang diatur oleh hukum. Sedangkan menurut Aristoteles suatu Negara yang baik adalah Negara yang diperintah dengan konstitusi dan berkedaulatan hukum. ${ }^{3}$

Dasar sistem ketatanegaraan Republik Indonesia tertuang jelas dan tegas dalam Bab I UUD 1945 tentang Bentuk dan Kedaulatan sebagaimana termuat dalam Pasal 1 ayat (1), (2) dan (3). Adapun dasar sistem ketatanegaraan tersebut sebagai berikut :

Pasal 1 ayat (1) UUD 1945 berbunyi bahwa :

Negara Indonesia adalah negara kesatuan yang berbentuk republik

Pasal 1 ayat (2) berbunyi :

Kedaulatan berada di tangan rakyat dan dilaksanakan menurut UUD Sedangkan Pasal 1 ayat (3) berbunyi bahwa :

Negara Indonesia adalah negara hukum.

Rumusan pasal di atas menunjukkan bahwa Bentuk Negara Indonesia adalah Kesatuan, bentuk pemerintahan adalah Republik dan sistem pemerintahan adalah Presidensial.

Sistem Pemerintahan Indonesia tercantum dalam pembukaan Undang-Undang Dasar 1945 yang menyatakan bahwa:

kemerdekaan kebangsaan Indonesia itu disusun dalam suatu Undang-Undang Dasar Negara Indonesia yang terbentuk dalam suatu susunan Negara Republik Indonesia yang berkedaulatan rakyat. $^{4}$

Prinsip negara republik adalah jika suatu negara pemilihan atau pembentukan kepala pemerintahannya melalui suara terbanyak dan kepala

${ }^{2}$ Pasal 1 ayat (3) UUD 1945

${ }^{3}$ Ni'matul Huda, Negara Hukum, Demokrasi, dan Judicial Review, UII Press, Yogyakarta, 2005, h. 1

${ }^{4}$ Pembukaan UUD 1945 
pemerintahannya itu disebut Presiden dan ditentukan dalam masa jabatannya. Menurut faham Duguit, ia menggunakan kriteria bagaimana caranya kepala negara itu diangkat, jika seorang kepala negara diangkat berdasarkan hak waris atau keturunan maka bentuk negaranya disebut Monarki dan kepala negaranya disebut Raja atau Ratu. Dan jika seorang kepala negara dipilih melalui suatu pemilihan umum untuk masa jabatan yang ditentukan maka bentuk negaranya disebut Republik dan kepala negaranya disebut Presiden. ${ }^{5}$

Dengan berpijak dari pendapat di atas dapat difahami bahwa bentuk negara Indonesia adalah Republik dimana kepala negaranya dijabat oleh Presiden yang dipilih melalui pemilihan umum dan dalam masa jabatan tertentu yaitu lima tahun.

Dalam Undang-Undang Dasar 1945 Pasal 4 ayat 1 ditentukan bahwa Presiden Republik Indonesia memegang kekuasaan Pemerintahan menurut Undang-Undang Dasar.

Rumusan di atas menunjukkan bahwa menurut konstitusi Sistem Pemerintahan Indonesia adalah menganut Sistem Presidensial dimana Presiden berkedudukan disamping sebagai kepala Pemerintahan juga sebagai kepala Negara. Namun prinsip Sistem Pemerintahan ini secara praktiknya tidak sesuai dengan amanat konstitusi.

Dalam Sistem Pemerintahan Presidensial, badan eksekutif dan legislatif memiliki kedudukan yang independen. Kedua badan tersebut tidak berhubungan secara langsung seperti dalam Sistem Pemerintahan Parlementer. Mereka dipilih oleh rakyat secara terpisah.

Para Sistem ini pula kepala Pemerintahan dipegang oleh Presiden dan pemerintah tidak bertanggung jawab kepada parlemen (legislatif). Menteri bertanggung jawab kepada Presiden karena Presiden berkedudukan sebagai kepala Negara dan kepala Pemerintahan.

Menurut Donald A. Rumokoy, Indonesia pernah menerapkan Sistem Pemerintahan Parlementer antara Oktober 1945 hingga sebelum Dekrit Presiden 5 Juli 1959. ${ }^{6}$ Oleh karena praktik Sistem Pemerintahan di Indonesia pernah mengalami perubahan dimana tidak sesuai dengan UUD 1945 maka perlu kiranya diadakan sebuah kajian tentang bagaimana Sistem Pemerintahan Indonesia berdasarkan UUD 1945 dan praktiknya di Indonesia baik sebelum amandemen maupun sesudahnya.

Praktik Sistem Pemerintahan dewasa ini juga perlu dikaji lebih lanjut apakah sudah sesuai dengan UUD 1945 ataukah perlu kiranya ada perubahan paradigma terkait dengan penerapan Sistem Pemerintahan yang implikasinya terhadap amandemen UUD 1945 yang kelima.

\footnotetext{
${ }^{5}$ Moh. Kusnardi, Harmally Ibrahim, 1988, Hukum Tata Negara Indonesia, Pusat Studi Hukum Tata Negara FH UI dan CV Sinar Bakti, Jakarta, hlm. 167

${ }^{6}$ Donald A. Rumokoy, Praktik Konvensi Ketatanegaraan di Indonesia- kajian perbandingan di Inggris, Amerika Serikat dan Belanda, Media Prima Aksara, Jakarta, 2011,hlm. 202
} 
B. Pembahasan

\section{Definisi Sistem Pemerintahan}

Istilah Sistem Pemerintahan berasal dari gabungan dua kata yaitu Sistem dan Pemerintahan. Sistem dalam Kamus Besar Bahasa Indonesia diartikan sebagai perangkat unsur yang secara teratur saling berkaitan sehingga membentuk suatu totalitas, susunan yang teratur dari pandangan teori, asas, dsb. ${ }^{7}$

Menurut Moh. Kusnardi Sistem adalah suatu keseluruhan, terdiri dari beberapa bagian yang mempunyai hubungan fungsional baik antara bagian-bagian maupun hubungan fungsional terhadap keseluruhannya, sehingga hubungan itu menimbulkan ketergantungan antara bagianbagian yang akibatnya jika salah satu bagian tidak bekerja dengan baik akan mempengaruhi keseluruhannya. ${ }^{8}$

Sedangkan Pemerintahan adalah proses, cara, perbuatan memerintah; segala urusan yang dilakukan oleh Negara dalam menyelenggarakan kesejahteraan masyarakat dan kepentingan Negara.

Pemerintahan dalam arti luas adalah pemerintah/lembaga Negara yang menjalankan segala tugas pemerintah baik sebagai lembaga eksekutif, legislatif dan yudikatif. Sedangkan menurut Donald A.Rumokoy istilah Pemerintahan dalam arti luas adalah segala urusan yang dilakukan oleh Negara dalam menyelenggarakan kesejahteraan rakyatnya dan kepentingan Negara sendiri, jadi di sini tidak hanya diartikan sebagai pemerintah yang hanya menjalankan tugas eksekutif saja akan tetapi juga meliputi tugas-tugas lainnya termasuk legislatif dan yudikatif.

Sistem Pemerintahan itu membicarakan bagaimana pembagian kekuasaan serta hubungan antara lembaga-lembaga Negara yang menjalankan kekuasaan-kekuasaan Negara itu dalam rangka menyelenggarakan kepentingan rakyat. ${ }^{10}$

Oleh karena itu, Sistem Pemerintahan itu adalah aturan atau cara bagaimana ketiga lembaga tersebut bekerja dan berhubungan satu sama lain dimana setiap lembaga harus bekerja sama dan menjalankan tugasnya dengan baik sehingga tujuan untuk menyelenggarakan kesejahteraan masyarakat dan kepentingan Negara dapat terwujud.

\section{Sistem Pemerintahan Indonesia sebelum Amandemen UUD 1945}

Sistem Pemerintahan Indonesia menurut UUD 1945 menganut Sistem Pemerintahan Presidensial. Sistem Pemerintahan ini dijalankan semasa

\footnotetext{
${ }^{7}$ Departemen Pendidikan dan Kebudayaan, Kamus Besar Bahasa Indonesia, Balai Pustaka, Jakarta, 2002, hlm. 1076

${ }^{8}$ Moh. Kusnardi, Harmally Ibrahim, op. cit., hlm. 171

${ }^{9}$ Donald A. Rumokoy, op. cit., hlm. 201

${ }^{10}$ Ibid., hlm. 171
} 
Pemerintahan Orde Baru di bawah kepemimpinan Presiden Suharto. Ciri dari Sistem Pemerintahan masa itu adalah adanya kekuasaan yang amat besar pada lembaga kepresidenan. Hampir semua kewenangan Presiden yang di atur menurut UUD 1945 tersebut dilakukan tanpa melibatkan pertimbangan atau persetujuan DPR sebagai wakil rakyat. Karena itu tidak adanya pengawasan dan tanpa persetujuan DPR, maka kekuasaan Presiden sangat besar dan cenderung dapat disalahgunakan. Mekipun adanya kelemahan, kekuasaan yang besar pada Presiden juga ada dampak positifnya yaitu Presiden dapat mengendalikan seluruh penyelenggaraan Pemerintahan sehingga mampu menciptakan Pemerintahan yang kompak dan solid. Sistem Pemerintahan lebih stabil, tidak mudah jatuh atau berganti. Konflik dan pertentangan antar pejabat negara dapat dihindari. Namun, dalam praktik perjalanan Sistem Pemerintahan di Indonesia ternyata kekuasaan yang besar dalam diri Presiden lebih banyak merugikan bangsa dan negara daripada keuntungan yang didapatkanya.

Dalam Sistem Pemerintahan Presidensial, badan eksekutif dan legislatif memiliki kedudukan yang independen. Kedua badan tersebut tidak berhubungan secara langsung seperti dalam Sistem Pemerintahan Parlementer. Mereka dipilih oleh rakyat secara terpisah.

Para Sistem ini pula kepala Pemerintahan dipegang oleh Presiden dan pemerintah tidak bertanggung jawab kepada parlemen (legislatif). Menteri bertanggung jawab kepada Presiden karena Presiden berkedudukan sebagai kepala Negara dan kepala Pemerintahan. Contoh : AS, Pakistan, Argentina, Brasil, Filiphina, Indonesia. Sedangkan dalam pemerintahan parlementer hubungan antara eksekutif dan legislative sangat erat. Pemerintah (eksekutif) bertanggung jawab kepada parlemen, parlemen mempunyai kekuasaan yang besar dan mempunyai kewenangan untuk melakukan pengawasan terhadap eksekutif. Menteri dan Perdana Menteri bertanggung jawab kepada parlemen.

Ciri-ciri Sistem Pemerintahan Presidensial adalah :

- Penyelenggara Negara berada di tangan Presiden. Presiden adalah kepala Negara sekaligus kepala Pemerintahan. Presiden dipilih langsung oleh rakyat atau suatu dewan majelis.

- Kepala negara tidak bertanggung jawab kepada parlemen, pemerintah dan parlemen sejajar (eksekutif tidak mempunyai kekuasaan untuk menyatu dengan legislatif). Hal itu dikarenakan Presiden tidak dipilih oleh parlemen atau legislatif, oleh karena itu Presiden langsung bertanggung jawab kepada rakyat yang memilihnya.

- Kedudukan kepala Negara tidak terpisah dari kedudukan kepala pemerintah 
- Presiden mengangkat Menteri dan bertanggung jawab kepadanya. Kabinet bertanggungjawab kepada Presiden dan tidak bertanggungjawab kepada parlemen atau legislatif (Menteri yang diangkat hanyalah pembantu Presiden)

- Presiden merupakan eksekutif tunggal

- Masa jabatan Presiden ditentukan dengan tegas

- Anggota parlemen tidak boleh menduduki jabatan eksekutif

- Presiden tidak dapat (berwenang) membubarkan ataupun memaksa parlemen

- Supremasi konstitusi

- Eksekutif bertanggung jawab pada rakyat yang berdaulat

- Parlemen memiliki kekuasaan legislatif dan sebagai lembaga perwakilan anggota parlemennya dipilih oleh rakyat. Demikian pula Eksekutif dipilih melalui pemilihan umum

- Kekuasaan tersebar ataupun tidak terpusat. ${ }^{11}$

Memasuki masa Reformasi ini, bangsa Indonesia bertekad untuk menciptakan Sistem Pemerintahan yang demokratis. Untuk itu, perlu disusun Pemerintahan yang konstitusional atau Pemerintahan yang berdasarkan pada konstitusi. Pemerintah konstitusional bercirikan bahwa konstitusi negara itu berisi

\section{Adanya pembatasan kekuasaan Pemerintahan atau eksekutif}

2. Jaminan atas hak asasi manusia dan hak-hak warga negara.

Berdasarkan hal itu, reformasi yang harus dilakukan adalah melakukan perubahan atau amandemen atas UUD 1945. Dengan mengamandemen UUD 1945 menjadi konstitusi yang bersifat konstitusional, diharapkan dapat terbentuk Sistem Pemerintahan yang lebih baik dari yang sebelumnya. Amandemen atas UUD 1945 telah dilakukan oleh MPR sebanyak empat kali, yaitu pada tahun 1999, 2000, 2001, dan 2002. Berdasarkan UUD 1945 yang telah diamandemen itulah menjadi pedoman bagi Sistem Pemerintahan Indonesia sekarang ini.

a. Periode Berlakunya UUD 1945

UUD 1945 pertama kali disahkan berlaku sebagai konstitusi Negara Indonesia dalam sidang Panitia Persiapan Kemerdekaan Indonesia pada tanggal 18 Agustus 1945. Naskah UUD 1945 yang diproklamasikan oleh Soekarno dan Mohammad Hatta dipersiapkan oleh suatu badan bentukan pemerintah balatentara Jepang "Dokuritsu Zyunbi Tyoosakai" yang berarti Badan

\footnotetext{
${ }^{11}$ www.google.co.id/\#sclient=psyab\&hl=id\&source=hp\&q=Sistem+pemerintah+Presidensial\&pbx $=1 \&$ oq $=$ Sistem + pemerintah+Presidensial
} 
Penyelidik Usaha-Usaha Persiapan Kemerdekaan Indonesia (BPUPKI). Badan ini tidak hanya melakukan usaha-usaha persiapan kemerdekaan sesuai dengan tujuan pembentukannya, tetapi malah mempersiapkan naskah Undang-Undang Dasar sebagai dasar untuk mendirikan Negara Indonesia merdeka. ${ }^{12}$

Setelah resmi disahkan pada tanggal 18 Agustus 1945, UUD 1945 ini tidak langsung dijadikan referensi dalam setiap pengambilan keputusan kenegaraan dan Pemerintahan. UUD 1945 pada pokoknya benar-benar dijadikan alat saja untuk sesegera mungkin membentuk Negara merdeka yang bernama Republik Indonesia. ${ }^{13}$ Menurut Bung Karno istilah UUD 1945 pada saat itu adalah revolutie-grondwet yang berarti bahwa Undang-Undang Dasar kilat dimana UUD tersebut akan diganti dengan yang baru apabila Negara merdeka sudah berdiri dan keadaan sudah memungkinkan. UUD 1945 dibuat karena adanya peluang untuk merdeka yang harus direbut dengan cepat dan untuk itu harus pula segera ditetapkan UUd bagi Negara yang digagas sebagai Negara demokrasi dan kinstitusional. ${ }^{14}$

Menurut Adnan Buyung Nasution bahwa tak dapat dibantah UUD 1945 itu sejak semula memang dimaksudkan sebagai UUD interim (sementara) untuk pada waktunya harus diperbaharui oleh MPR hasil pemilu. ${ }^{15}$ Oleh karena UUD saat itu masih bersifat interim (sementara) dimana tujuaannya hanyalah mengantarkan Indonesia menjadi Negara merdeka maka pengambilan keputusan dalam Sistem Pemerintahan tidak mengikat mengacu pada Sistem UUD tersebut. Sebagai contoh adalah menurut ketentuan UUD 1945 Sistem Pemerintahan yang dianut adalah Sistem Presidensiil, atas dasar itu maka pada tanggal 2 september 1945 dibentuklah susunan kabinet pertama di bawah tangggung jawab Presiden Soekarno. Akan tetapi baru dua bulan setelah itu tanggal 14 november 1945 pemerintah mengeluarkan maklumat yang berisi perubahan Sistem kabinet dari Sistem Presidensiil (quasi Presidensiil) ke Sistem Parlementer.

12 Jimly Asshiddiqie, Konstitusi dan Konstitusionalisme Indonesia, Konstitusi Press, Jakarta, 2006, h. 39

${ }^{13}$ Ibid

14 Moh Mahfud MD, Perdebatan Hukum Tata Negara Pascaamandemen Konstitusi, PT Raja Grafindo Persada, Jakarta, 2011, h.21

${ }^{15}$ Adnan Buyung Nasution sering mengemukakan bahwa salah satu alasan mengapa UUD 1945 harus diamandemen adalah karena UUD itu dibuat oleh lembaga yang bukan hasil pemilu. Padahal idealnya UUD harus dibuat oleh lembaga perwakilan/permusyawaratan rakyat yang dibentuk melalui pemilu. 
Menurut Jimly Asshiddiqie bahwa UUD 1945 yang disahkan pada tanggal 18 Agustus 1945 hanya dalam waktu tidak sampai tiga bulan Sistem Pemerintahan menyimpang dari UUD 1945 yaitu dengan dibentuknya kabinet Parlementer pertama di bawah Perdana Menteri Sutan Syahrir pada tanggal 14 Nopember 1945. Padahal UUD 1945 yang baru disahkan itu jelas tidak menagnut Sistem Pemerintahan Parlementer dan tidak mengenal jabatan Perdana Menteri sama sekali. Sistem Pemerintahan Parlementer itu terus dipraktikkan sampai periode berlakunya UUD RIS tahun 1949 dan UUDS tahun 1950. Bahkan setelah dekrit Presiden 5 Juli 1959 yang kembali memberlakukan UUD 1945 sebagai konstitusi Republik Indonesia, Sistem Pemerintahan yang dipraktikkan juga adalah Sistem Parlementer. ${ }^{16}$

Sistem Pemerintahan Negara mengalami perubahan fundamental setelah Presiden menyetujui usulan Badan Pekerja Komite Nasional pada tanggal 11 November 1945 yang diwujudkan dengan dikeluarkannya Maklumat Pemerintah tanggal 14 November $1945 .{ }^{17}$ Sehubungan dengan itu pemerintah menetapkan kebijakan untuk membentuk kabinet Parlementer pertama di bawah Perdana Menteri Syahrir. ${ }^{18}$ Sebagaimana difahami bahwa dalam UUD 1945 menganut Sistem Presidensiil, sama sekali tidak mengatur Sistem Parlementer. Periode 18 Agustus 1945 sampai 27 Desember 199 itu konstitusi Indonesia hanyalah berada di atas kertas saja.

Maklumat pemerintah tersebut didahului oleh keluarnya Maklumat wakil Presiden No. X tanggal 16 Oktober 1945 yang pada diktumnya menegaskan sebagai berikut :

"Bahwa komite nasional pusat sebelum terbentuknya Majelis Permusyawaratan Rakyat dan Dewan Perwakilan Rakyat diserahi kekuasaan legislatif dan ikut menetapkan garis-garis besar daripada haluan Negara"

Maklumat ini juga menentukan bahwa berhubung dengan gentingnya keadaan, mendelegasikan kekuasaannya kepada sebuah Badan Pekerja yang dipilih diantara mereka dan yang bertanggungjawab kepada Komite Nasional Pusat. ${ }^{19}$

\footnotetext{
${ }^{16}$ Jimly Asshiddiqie, Pokok-pokok Hukum Tata Negara Indonesia Pasca Reformasi, PT Bhuana IImu Populer Kelompok Gramedia, Jakarta Barat, 2008, hlm. 321

${ }^{17}$ Donald A. Rumokoy, op. cit., hlm. 208

${ }^{18}$ Jimly Asshiddiqie, 2006, op. cit., hlm. 43

${ }^{19}$ Jimly Asshiddiqie, 2008, op. cit., hlm. 322
} 
Dalam Sistem yang diperkenalkan oleh Maklumat Nomor X tanggal 16 Oktober 1945 dan Maklumat Pemerintah tanggal 14 November 1945, Menteri ditentukan bertanggung jawab kepada Komite Nasional Pusat, dan pimpinan Kabinet disebut Perdana Menteri. Sebelum terbentuknya Kabinet Syahrir I, kabinet pertama yang dibentuk adalah kabinet Presidensial di bawah tanggung jawab Presiden, yaitu kabinet yang bekerja antara tanggal 2 September - 14 November 1945. Setelah berubah menjadi kabinet Parlementer Syahrir I pada tanggal 14 November 1945, dapat dikatakan bahwa Pemerintahan selanjutnya menerapkan Sistem Parlementer. Selanjutnya, kabinet presdiensial kembali dibentuk setelah kabinet Amir Syarifuddin II dibubarkan pada tanggal 29 Januari 1948, yaitu tanggal 29 Januari 1948 s.d. 4 Agustus 1949. Kabinet kedua ini dirombak pada tanggal 4 Agustus 1949 dan terus bekerja sampai dengan 20 Desember $1949 .^{20}$

b. Sistem Pemerintahan Indonesia Tahun 1949

Selama periode pertama berlakunya UUD 1945 telah terjadi peperangan antara Indonesia yang mempertahankan kemerdekaannya dan Belanda yang hendak menjajah kembali. ${ }^{21}$ Setelah PD kedua berakhir maka pemerintah Belanda yang telah menjajah Indonesia 3,5 abad berkeinginan kembali inigin menjajah Indonesia lagi. Namun usaha mereka tidak berhasil oleh karena mendapatkan perlawanan yang sengit dari para pejuang bangsa. Oleh karena pemerintah Belanda tidak berhasil, maka mereka mengembangkan politik adu domba dengan cara mendirikan dan mensponsori berdirinya Negara kecil di wilayah Indonesia yaitu Negara Sumatera, Negara Indonesia Timur, Negara Pasundan, Negara Jawa Timur, dsb. ${ }^{22}$ Di samping itu tentara Belanda juga melakukan agresi I tahun 1947 dan agresi II tahun 1948. Dalam kondisi yang terdesak maka pada tanggal 23 Agustus 1949 sampai 2 november 1949 diadakanlah Konperensi Meja Bundar (KMB) di Den Haag. Dimana salah satu isi konperensi tersebut yang disepakati yaitu: mendirikan Negara Republik Indonesia Serikat (RIS). Naskah konstitusi RIS disusun bersama oleh delegasi RI dan Panitia Urusan Pemufakatan Federal (Byeenkomst voor Federal Overleg) ke KMB itu. Delegasi Indonesia Mr.Mohammad Roemdan Prof. Dr. Soepomo telah mempersiapkan naskah UUD sehingga rancangan tersebut dalam KMB disepakati menjadi Konstitusi RIS. Kemudian disampaikan kepada Komite Nasional Pusat (lembaga perwakilan rakyat) dan disahkan berlaku pada

${ }^{20}$ Ibid., hlm. 323

${ }^{21}$ Sri Soemantri M, Bunga Rampai Hukum Tata Negara Indonesia, Alumni, Bandung, 1992, hlm. 136

${ }^{22}$ Jimly Asshiddiqie, 2006, op. cit., hlm. 44 
tanggal14 desember 1949. Masa berlakunya RIS yaitu 27 Agustus 1950, ketika UUDS 1950 resmi diberlakukan.

Sistem Pemerintahan yang dianut olek Konstitusi RIS adalah Sistem Parlementer Kabinet Semu (Quasi Parlementer) dan bukan kabinet parlemen murni. ${ }^{23}$ Dengan penjelasan :

- Pengangkatan Perdana Menteri dan pembentukan kabinet dilakukan oleh Presiden dan bukan oleh parlemen sebagaimana lazimnya

- Kekuasaan Perdana Menteri masih dicampur tangan oleh Presiden. Padahal Presiden merupakan kepala Negara dan Perdana Menteri adalah kepala Pemerintahan

- Pertanggungjawaban Menteri adalah kepada DPR, namun harus melalui keputusan pemerintah

- Parlemen tidak mempunyai hubungan erat dengan pemerintah sehingga DPR tidak mempunyai pengaruh besar kepada pemerintah. $^{24}$

c. Sistem Pemerintahan di bawah UUDS

Bentuk Negara federal nampaknya mengandung banyak nuansa politik, berkenaan dengan kepentingan penjajahan Belanda. Karena itu, meskipun gagasan bentuk Negara federal mungkin saja memiliki relevansi sosiologis yang cukup kuat untuk diterapkan di Indonesia. $^{25}$

Bentuk Negara federal di masa Pemerintahan RIS dalam bentuk Negara federal tidaklah bertahan lama. Tiga Negara bagian yaitu Negara Republik Indonesia, Negara Indonesia Timur dan Negara Sumatera Timur menggabungkan diri menjadi satu wilayah RepublikIndonesia. Sejak saat itulah Pemerintahan RIS mulai berkurang sehingga dicapailah sebuah kesepakatan mendirikan Negara Kesatuan Republik Indonesia (NKRI) yang terjadi pada tanggal 19 Mei 1950 sebagai kelanjutan dari Negara Kesatuan yang diproklamasikan pada tanggal 17 Agustus 1945.

Konstitusi RIS dan UUDS ini hanya bersifat sementara. Sebagaimana dirumuskan dalam pasal 134 bahwa keharusan konstituante bersama-sama dengan pemerintah segera menyusun Udang-Undang Dasar Republik Indonesia yang akan mengganti

\footnotetext{
${ }^{23}$ www.slideshare.net/omcivics/pelaksanaan-Sistem-Pemerintahan-di-indonesia-ericpresentation

${ }^{24}$ www.slideshare.net/omcivics/pelaksanaan-Sistem-Pemerintahan-di-indonesia-ericpresentation

${ }^{25}$ Jimly Asshiddiqie, 2006, op. cit., hlm. 46
} 
UUDS tahun 1950 itu. UUDS berhasil menyelenggarakan pemilu pada bulan Desember 1955 yang bertujuan untuk memilih anggota konstituante yang kemudian diresmikan di kota Bandung pada tanggal 10 November 1956. Majelis konstituante yang dipilih melalui pemilu tidak berhasil menjalankan tugasnya untuk menyusun UUD baru sehingga Presiden Soekarno beranggapan bahwa konstituante gagal dan atas dasar itulah ia mengeluarkan Dekrit Presiden 5 Juli 1959 dimana memberlakukan kembali UUD 1945 sebagai UUD Negara Republik Indonesia.

Sesudah dekrit 5 Juli 1959 berarti kembali berlaku UndangUndang Dasar 1945, sebab dekrit tersebut itulah merupakan sumber hukum bagi berlakunya UUD 1945 tersebut. $^{26}$

\section{d. Pemberlakuan Kembali UUD 1945 pada Demokrasi Terpimpin}

Setelah pemberlakuan UUD 1945 kembali, rakyat menaruh harapan akan kehidupan ketatanegaraan yang stabil dan pemerintah Presidensial yang demokratis. Akan tetapi, dengan penerapan Demokrasi Terpimpin menyebabkan terjadinya penyimpangan terhadap Pancasila dan UUD. ${ }^{27}$ Adapun bentuk penyimpangannya adalah :

a. Penyimpangan ideologis, konsepsi Pancasila diganti dengan Nasakom

b. Pemusatan kekuasaan Presiden dengan wewenang yang melebihi ketentuan UUD 1945, yaitu membentuk produk hukum tanpa persetujuan dari DPR

c. Dalam MPRS NO III/MPRS/1963 mengangkat Ir. Soekarno sebagai Presiden seumur hidup.

d. Kedudukan MPRS dan DPRS dijadikan Menteri negara sebagai pembantu Presiden. ${ }^{28}$

Dengan berlakunya kembali UUD tanggal 5 Juli 1959, Indonesia memasuki periode demokrasi terpimpin. UUD 1945 menggunakan Sistem Pemerintahan Presidensial. Presiden Soekarno menjadi Kepala Negara sekaligus sebagai Kepala Pemerintahan RI Sistem kepemimpinannya disebut orde lama.

Inkonsistensi penerapan Sistem Pemerintahan ini merupakan bentuk penyimpangan terhadap ketentuan UUD 1945 sendiri yang

\footnotetext{
${ }^{26}$ Hartono Hadisoeprapto, Pengantar Tata Hukum Indonesia, Cet. Kelima, Liberty, Yogyakarta, 2001, hlm. 20

${ }^{27}$ www.slideshare.net/omcivics/pelaksanaan-Sistem-Pemerintahan-di-indonesia-ericpresentatio

${ }^{28}$ www.slideshare.net/omcivics/pelaksanaan-Sistem-Pemerintahan-di-indonesia-ericpresentation
} 
jelas-jelas mengatur Sistem Pemerintahan Presidensial. Namun keinkonsistensian penerapan Sistem Pemerintahan tersebut didasari atas konvensi ketatanegaraan dan hukum kebiasaan yang telah diterapkan sebelumnya. Disamping itu juga dapat dikatakan karena UUD 1945 sendiri memang dimaksudkan hanya sebagai revolutie - grondwet atau undang-undang dasar kilat (ucapan Bung Karno dalam sidang BPUPKI) yaitu undang-undang dasar yang hanya dimaksudkan sebagai naskah konstitusi untuk sementara waktu dalam rangka persiapan Indonesia menjadi Negara yang merdeka dan berdaulat. ${ }^{29}$ Oleh karena itu, dapat dimaklumi bahwa UUD 1945 itu sendiri sejak masa awal kemerdekaan RI belum dijadikan referensi akan tetapi hanya sebagai sebuah syarat persiapan kemerdekaan Indonesia.

e. Sistem Pemerintahan pada Orde Baru

Selama rezim Orde Baru tidak terjadi perubahan Sistem Pemerintahan. Akan tetapi, pelaksanaan lembaga kePresidenan sangat dominan. Hal ini dapat dilihat di dalam UUD 1945 yang menyatakan tugas dan kewenangan Presiden mencakup tidak hanya bidang eksekutif, tetapi juga dalam bidang legislatif dan yudikatif. Selain itu, kelembagaan negara dan organisasi sosial politik cenderung berjalan kurang seimbang dan proposional. ${ }^{30}$

Pelaksanaan UUD 195 sebagai referensi Sistem ketatanegaraan baru dipraktikkan secara nyata pada masa orde baru. Jargon yang sering dipakai pada Pemerintahan ini adalah pelaksanaan UUD 1945 secara murni dan konsekuen.

Orde Baru telah berhasil menyelenggarakan Pemerintahan melalui mekanisme kenegaraan yang dikenal dengan Mekanisme Kepemimpianan Nasional 5 tahun. Mekanisme Kepemimpinan Nasional 5 tahun tersebut adalah:

1. Diadakannya pemilu untuk mengisi keanggotaan MPR, DPR, DPRD I, DPRD II.

2. MPR bersidang untuk memilih Presiden dan wakil Presiden serba menetapkan GBHN untuk 5 tahun.

3. Presiden membentuk kabinet yang bertanggungjawab terhadap Presiden. Kabinet melaksanakan tugas dibawah petunjuk Presiden dengan berlandaskan UUD dan GBHN.

\footnotetext{
${ }^{29}$ Jimly Asshiddiqie, 2008, op. cit., 325

${ }^{30}$ www.slideshare.net/omcivics/pelaksanaan-Sistem-Pemerintahan-di-indonesia-ericpresentation
} 
4. Presiden bertanggung jawab kepada MPR. Presiden menyampaikan laporan pertanggungjawaban setiap akhir kepemimpinan kepada MPR.

5. DPR mengawasi jalannya Pemerintahan. DPR bersama Presiden membentuk UU.

Pada masa orde baru, tanggung jawab kekuasaan Negara terpusat di tangan Presiden (menganut Sistem Presidensial). Kedudukan Presiden sangat kuat sehingga meskipun MPR sebagai lembaga tertinggi Negara (tempat Presiden diharuskan tunduk dan bertanggung jawab) tetapi dalam kenyataannya kedudukan MPR tergantung pada Presiden. Adanya unsur pertanggungjawaban presdien kepada MPR justru memperlihatkan ciri Parlementer. Oleh karena itulah, secara normatif Sistem yang dianut oleh UUD 1945 bukanlah murni Sistem Presidensial akan tetapi hanya quasi Presidensial.

Sifat quasi atau Sistem Presidensial tidak murni itulah yang diubah ketika UUD 1945 diubah pada tahun1999 sampai tahun 2002, yaitu dengan mengubah kedudukan MPR tidak lagi sebagai lembaga tertinggi Negara, melainkan lembaga Negara yang sederajat dengan Presiden. Disamping itu, perubahan UUD 1945 itu juga mengatur tentang pemilihan Presiden dan wakil Presiden oleh rakyat melalui pemilihan umum setiap lima tahun sekali. ${ }^{31}$

\section{Sistem Pemerintahan di Indonesia setelah Amandemen UUD 1945}

Sekarang ini Sistem Pemerintahan di Indonesia masih dalam masa transisi. Sebelum diberlakukannya Sistem Pemerintahan baru berdasarkan UUD 1945 hasil amandemen keempat tahun 2002, Sistem Pemerintahan Indonesia masih mendasarkan pada UUD 1945 dengan beberapa perubahan seiring dengan adanya transisi menuju Sistem Pemerintahan yang baru. Sistem Pemerintahan baru diharapkan berjalan mulai tahun 2004 setelah dilakukannya Pemilu 2004.

Undang-Undang Dasar merupakan hukum tertinggi dimana kedaulatan berada di tangan rakyat dan dijalankan sepenuhnya menurut UUD. UUD memberikan pembagian kekuasaan (separation of power) kepada enam lembaga Negara dengan kedudukan yang sama dan sejajar, yaitu Presiden, Majelis Permusyawaratan Rakyat (MPR), Dewan Perwakilan Rakyat (DPR), Dewan Perwakilan Daerah (DPD), Badan Pemeriksa

${ }^{31}$ Jimly Asshiddiqie, 2008, op. cit. hlm. 326 
Keuangan (BPK), Mahkamah Agung (MA), Mahkamah Konstitusi $(\mathrm{MK}) .^{32}$

Perubahan amandemen UUD 1945 yaitu :

- Mempertegas prinsip Negara berdasarkan atas hukum (Pasal 1 ayat (3) dengan menempatkan kekuasaan kehakiman sebgai kekuasaan yang merdeka, penghormatan kepada hak asasi manusia serta kekuasaan yang dijalankan atas prinsip due process of law

- Mengatur mekanisme pengangkatan dan pemberhentian para pejabat Negara, seperti hakim

- Sistem konstitusional berdasarkan perimbangan kekuasaan (check and balances) yaitu setiap kekuasaan dibatasi oleh UndangUndang berdasarkan fungsi masing-masing

- Setiap lembaga Negara sejajar kedudukannya di bawah UUD 1945

- Menata kembali lembaga-lembaga Negara yang ada serta membentuk beberapa lembaga Negara baru agar sesuai dengan sistem konstitusional dan prinsip Negara berdasarkan hukum

- Penyempurnaan pada sisi kedudukan dan kewenangan masingmasing lembaga Negara disesuaikan dengan perkembangan Negara demokrasi modern. ${ }^{33}$

Pokok-pokok Sistem Pemerintahan Indonesia adalah sebagai berikut.

1. Bentuk negara Kesatuan dengan prinsip otonomi daerah yang luas. Wilayah negara terbagi dalam beberapa propinsi.

2. Bentuk Pemerintahan adalah Republik, sedangkan Sistem Pemerintahan Presidensial.

3. Presiden adalah kepala negara dan sekaligus kepala Pemerintahan. Presiden dan wakil Presiden dipilih dan diangkat oleh MPR untuk masa jabatan lima tahun. Untuk masa jabatan 2004-2009, Presiden dan wakil Presiden akan dipilih secara langsung oleh rakyat dalam satu paket.

4. Kabinet atau Menteri diangkat oleh Presiden dan bertanggung jawab kepada Presiden.

5. DPR memiliki kekuasaan mengawasi jalannya Pemerintahan. Presiden dapat diberhentikan oleh MPR atas usul DPR

6. DPR memiliki fungsi pengawasan, legislasi dan anggaran.

7. Parlemen terdiri atas dua bagian (bikameral), Dewan Perwakilan Rakyat (DPR) dan Dewan Perwakilan Daerah (DPD). Para anggota

\footnotetext{
${ }^{32}$ http://panmohamadfaiz.com/2007/03/18/sistem-ketatanegaraan-indonesia-pasca amandemen/

${ }^{33} \mathrm{http}: / /$ panmohamadfaiz.com/2007/03/18/sistem-ketatanegaraan-indonesia-pascaamandemen/
} 
dewan merupakan anggota MPR. DPR memiliki kekuasaan legislatif dan kekuasaan mengawasi jalannya Pemerintahan.

8. Kekuasaan yudikatif dijalankan oleh Makamah Agung dan badan peradilan dibawahnya.

Sistem Pemerintahan ini juga mengambil unsur-unsur dari Sistem Pemerintahan Parlementer dan melakukan pembaharuan untuk menghilangkan kelemahan-kelemahan yang ada dalam Sistem Presidensial. Beberapa variasi dari Sistem Pemerintahan Presidensial di Indonesia adalah sebagai berikut.

1. Presiden sewaktu-waktu dapat diberhentikan oleh MPR atas usul dari DPR. Jadi, DPR tetap memiliki kekuasaan megawasi Presiden meskipun secara tidak langsung.

2. Presiden dalam mengangkat pejabat negara perlu pertimbangan atau persetujuan dari DPR. Contohnya dalam pengangkatan duta negara asing, Gubernur Bank Indonesia, Panglima TNI, dan Kepala Kepolisian.

3. Presiden dalam mengeluarkan kebijakan tertentu perlu pertimbangan atau persetujuan dari DPR. Contohnya, pembuatan perjanjian Internasional, pemberian gelar, tanda jasa, tanda kehormatan, pembrian amnesti, dan abolisi.

4. Parlemen diberi kekuasaan yang lebih besar dalam hal membentuk undang-undang dan hak budget (anggaran)

Dengan demikian, ada perubahan-perubahan baru dalam Sistem Pemerintahan Indonesia. Hal itu diperuntukan dalam memperbaiki Sistem Presidensial yang lama. Perubahan baru tersebut, antara lain adanya pemilihan secara langsung, Sistem bikameral, mekanisme cheks and balance, dan pemberian kekuasaan yang lebih besar kepada parlemen untuk melakukan pengawasan dan fungsi anggaran.

Kekuasaan dalam negara dibagi dalam dua hal yaitu pemisahan kekuasaan (separation of power) dan pembagian kekuasaan (distribution of power). Hubungan antara lembaga-lembaga negara yang sederajat dan saling mengimbangi disebut sebagai pemisahan kekuasaan negara yang bersifat horizontal. Sedangkan pembagian kekuasaan kepada lembaga-lembaga tinggi negara di bawah lembaga pemegang kedaulatan rakyat disebut sebagai pembagian kekuasaan yang bersifat vertikal.

Pembagian kekuasaan secara vertical di bawah lembaga pemegang kedaulatan rakyat (MA dan MK) telah diberikan kewenangan kepada masing-masing peradilan yaitu peradilan umum, peradilan agama, peradilan militer dan peradilan tata usaha negara. Keempat peradilan tersebut memiliki kewenangan untuk menerima, memeriksa, 
menyelesaikan dan memutus perkara berdasarkan kompetensi relatif dan kompetensi absolut yang dimilikinya.

Demikian pula kewenangan yang diberikan kepada daerah propinsi, kabupaten dan kota. Menurut Pasal 18 UUD 1945 bahwa NKRI dibagi atas daerah-daerah propinsi dan daerah propinsi itu dibagi atas kabupaten dan kota, yang tiap-tiap propinsi, kabupaten dan kota itu mempunyai pemerintahan daerah yang diatur dengan undangundang.

Dalam UU Nomor 32 tahun 2004 tentang pemerintahan daerah, pda pasal 1 ayat (5) dinyatakan bahwa otonomi daerah adalah hak, wewenang, dan kewajiban daerah untuk mengatur dan mengurus sendiri urusan pemerintahan dan kepentingan masyarakat setempat sesuai dengan peraturan perundang-undangan. ${ }^{34}$

Hal ini bahwa lembaga kedaulatan rakyat (dalam hal ini Presiden) memberikan kewenangan kepada daerah untuk mengatur dan mengurus daerah. Kewenangan tersebut adalah kewenangan yang bersifat vertikal.

Sistem pengawasan antara legislative, eksekutif dan legislatif sangat dibutuhkan dimana setelah amandemen UUD 1945 telah dirumuskan sistem pengawasan dan keseimbangan (sistem check and balance). Ketiga lembaga tersebut menjalankan tugas pokok dan fungsinya mengacu atau berpedoman pada UUD 1945.

Hubungan antara Lembaga negara (Presiden dan Legislatif/DPR) sangat erat. Hal dapat dilihat dari bentuk persetujuan dan pertimbangan DPR yang diberikan kepada Presiden. Presiden dalam melaksanakan tugasnya perlu mendapat persetujuan dari DPR. Persetuan DPR tersebut dalam hal menyatakan perang, membuat perdamaian, perjanjian dengan negara lain dan mengharuskan perubahan atau pembentukan undang-undang, mengangkat hakim agung yang diusulkan oleh KY, mengangkat dan meberhentikan anggota KY. Hal tersebut di atas merupakan suatu hal yang mutlak bahwa Presiden dalam menjalankan tugasnya harus ada persetujuan DPR. Demikian pula DPR memberikan pertimbangan kepada Presiden dalam kaitannya dengan mengangkat duta, konsul, menerima penempatan duta negara lain, memberi amnesti dan abolisi, mengajukan rancangan undangundang tentang APBN.

Hubungan antara Presiden dan Legislatif merupakan hubungan yang horizontal dalam hal saling mengawasi. Akan tetapi, DPR memiliki kekuasaan mengawasi secara tidak langsung terhadap Presiden sebab MPR dapat memberhentikan Presiden atas usul DPR. Padahal dalam

${ }^{34}$ Pasal 1 ayat (5) Undang-Undang Nomor 32 Tahun 2004 tentang Pemerintah Daerah 
sistem pemerintahan Presidensial itu kedaulatan berada di tangan rakyat dan dilakukan menurut UUD. Menurut penulis MPR yang dipilih langsung oleh rakyat tetap memiliki kewenangan yang besar terhadap Presiden walaupun ia bukanlah lembaga tertinggi negara. Dalam pemerintahan parlementer hubungan antara eksekutif dan legislatif itu sangat erat. Sebab badan eksekutif dipilih oleh parlemen. Akan tetapi pada pemerintahan presidensial masing-masing lembaga negara melaksanakan tugasnya (separation of power) berdasarkan UUD 1945. Jadi, sistem pengwasan DPR secara tidak langsung dan juga MPR dapat memberhentikan Presiden merupakan sebuah sistem pemerintahan parlementer bukan presidensial. Hal tersebut dipraktikkan di Indonesia. Demikian pula adanya persetujuan dan pertimbangan DPR kepada Presiden menggambarkan bahwa hubungan antara kedua badan tersebut sangat erat.

Presiden sebagai lembaga negara memiliki kekuasaan pemerintahan negara sebagaimana tercantum dalam Pasal 4 ayat (1) yaitu Presiden Republik Indonesia memegang kekuasaan pemerintahan menurut Undang-Undang Dasar. Dan juga dalam ayat (2) yaitu dalam melakukan kewajibannya Presiden dibantu oleh satu orang Wakil Presiden.

Presiden dalam melaksanakan tugas pemerintahan dibantu oleh para menteri-menteri. Dimana para menteri tersebut diangkat dan diberhentikan oleh Presiden dan bertanggung jawab kepada Presiden. Sebagaiman tercantum dalam Pasal 17 UUD 1945 yaitu : (1) Presiden dibantu oleh menteri-menteri negara, (2) Menteri-menteri itu diangkat dan diberhentikan oleh Presiden, (3) Setiap menteri membidangi urusan tertentu dalam pemerintahan.

UUD 1945 telah empat kali mengalami perubahan yaitu tahun 1999, 2000, 2001, dan 2002. Salah satu kesepakatan panitia AD HOC tentang perubahan UUD 1945 adalah mempertegas Sistem Pemerintahan Presidensial.

Berdasarkan UUD 1945, Sistem Pemerintahan yang dipakai tetap Sistem Pemerintahan Presidensial. Namun, untuk mengembangkan Sistem Pemerintahan yang bersih adalah Sistem Pemerintahan yang demokratis maka UUD 1945 perlu diamandemen. UUD 1945 telah mengalami empat kali perubahan dan diharapkan dapat menciptakan Sistem Pemerintahan Presidensial yang bersih dan demokratis. Selain Sistem ini tetap dipertahankan, diperkuat juga melalui mekanisme pemilihan Presiden dan wakil Presiden secara langsung.

Dalam Pasal 6A ayat (2) UUD 1945 telah dinyatakan bahwa pasangan calon Presiden dan Wakil Presiden diusulkan oleh partai politik atau gabungan partai politik peserta pemilihan umum sebelum pelaksanaan pemilihan umum. 
Menurut penulis bahwa pasal di atas memberikan peluang yang besar bagi partai politik dalam melakukan bargaining politik terhadap Presiden terkait dengan pengangkatan Menteri-menteri sebagaimana yang diamanatkan dalam UUD 1945.

Praktik pemerintahan sekarang ini mengalami beberapa perubahan. Hal ini dapat dilihat bahwa dalam sistem pemerintahan presidensial, presiden mengangkat Menteri dan bertanggung jawab kepadanya. Dalam hal pengangkatan Menteri-menteri tersebut dalam Kabinet Indonesia Bersatu kebanyakan mereka diangkat dari partai koalisi pemerintah. Partai pemerintah adalah Demokrat. Diantara partai koalisi pemerintah tersebut adalah PKS, PAN, dan PKB. Ketiga partai koalisi ini menduduki jabatan sebagai Menteri pada Kabinet Indonesia Bersatu (KIB).

Partai koalisi memiliki peran yang sangat strategis dalam menjalankan pemerintahan SBY-Boediono. Partai-partai koalisi memiliki kader yang duduk sebagai wakil rakyat di Dewan Perwakilan Rakyat (DPR). Relevansinya dengan Menteri-Menteri yang diangkat sebagai pembantu presiden adalah memiliki ikatan yang sangat kuat dan erat yaitu ikatan kepartaian dan juga ikatan emosional (karena mereka yang duduk di DPR dan mereka yang menjabat sebagai Menteri masingmasing dari partai yang sama). Oleh karena itu, sangat tidak mungkin saling menjatuhkan.

Hal yang perlu menjadi pertimbangan presiden dalam mengangkat ataupun melakukan resufle kabinet (sebagai yang telah dilakukan barubaru ini) adalah meminimalisir pengangkatan Menteri dari kalangan partai koalisi. Kalangan professional, akademisi, praktisi perlu menjadi pertimbangan khusus SBY terhadap pengangkatan MenteriMenterinya.

\section{Perbandingan Sistem Pemerintahan dengan Negara-Negara Lain}

Sistem Pemerintahan negara-negara didunia ini berbeda-beda sesuai dengan keinginan dari negara yang bersangkutan dan disesuaikan dengan keadaan bangsa dan negaranya. Sebagaimana dikemukakan sebelumnya, Sistem Pemerintahan Presidensial dan Sistem Pemerintahan Parlementer merupakan dua model Sistem Pemerintahan yang dijadikan acuan oleh banyak negara. Amerika Serikat dan Inggris masing-masing dianggap pelopor dari Sistem Pemerintahan Presidensial dan Sistem Pemerintahan Parlementer. Dari dua model tersebut, kemudian dicontoh oleh negara-negar lainnya.

Contoh negara yang menggunakan Sistem Pemerintahan Presidensial: Amerika Serikat, Filipina, Brasil, Mesir, dan Argentina. Dan contoh negara yang menggunakan Sistem Pemerintahan parlemen: Inggris, India, Malaysia, Jepang, dan Australia. 
Meskipun sama-sama menggunakan Sistem Presidensial atau Parlementer, terdapat variasi-variasi disesuaikan dengan perkembangan ketatanegaraan negara yang bersangkutan. Misalnya, Indonesia yang menganut Sistem Pemerintahan Presidensial tidak akan sama persis dengan Sistem Pemerintahan Presidensial yang berjalan di Amerika Serikat. Bahkan, negara-negara tertentu memakai Sistem campuran antara Presidensial dan Parlementer (mixed parliamentary Presidential Sistem). Contohnya, negara Prancis sekarang ini. Negara tersebut memiliki Presiden sebagai kepala negara yang memiliki kekuasaan besar, tetapi juga terdapat Perdana Menteri yang diangkat oleh Presiden untuk menjalankan Pemerintahan sehari-hari.

Sistem Pemerintahan suatu negara berguna bagi negara lain. Salah satu kegunaan penting Sistem Pemerintahan adalah Sistem Pemerintahan suatu negara menjadi dapat mengadakan perbandingan oleh negara lain. Suatu negara dapat mengadakan perbandingan Sistem Pemerintahan yang dijalankan dengan Sistem Pemerintahan yang dilaksakan negara lain. Negara-negara dapat mencari dan menemukan beberapa persamaan dan perbedaan antarSistem Pemerintahan. Tujuan selanjutnya adalah negara dapat mengembangkan suatu Sistem Pemerintahan yang dianggap lebih baik dari sebelumnya setelah melakukan perbandingan dengan negara-negara lain. Mereka bisa pula mengadopsi Sistem Pemerintahan negara lain sebagai Sistem Pemerintahan negara yang bersangkutan.

Para pejabat negara, politisi, dan para anggota parlemen negara sering mengadakan kunjungan ke luar negeri atau antarnegara. Mereka melakukan pengamatan, pengkajian, perbandingan Sistem Pemerintahan negara yang dikunjungi dengan Sistem Pemerintahan negaranya. Seusai kunjungan para anggota parlemen tersebut memiliki pengetahuan dan wawasan yang semakin luas untuk dapat mengembangkan Sistem Pemerintahan negaranya.

Pembangunan Sistem Pemerintahan di Indonesia juga tidak lepas dari hasil mengadakan perbandingan Sistem Pemerintahan antarnegara. Sebagai negara dengan Sistem Presidensial, Indonesia banyak mengadopsi praktik-praktik Pemerintahan di Amerika Serikat. Misalnya, pemilihan Presiden langsung dan mekanisme cheks and balance. Konvensi Partai Golkar menjelang pemilu tahun 2004 juga mencontoh praktik konvensi di Amerika Serikat. Namun, tidak semua praktik Pemerintahan di Indonesia bersifat tiruan semata dari Sistem Pemerintahan Amerika Serikat. Contohnya, Indonesia mengenal adanya lembaga Majelis Permusyawaratan Rakyat, sedangkan di Amerika Serikat tidak ada lembaga semacam itu. 
Dengan demikian, Sistem Pemerintahan suatu negara dapat dijadikan sebagai bahan perbandingan atau model yang dapat diadopsi menjadi bagian dari Sistem Pemerintahan negara lain. Amerika Serikat dan Inggris masing-masing telah mampu membuktikan diri sebagai negara yang menganut Sistem Pemerintahan Presidensial dan Parlementer seara ideal. Sistem Pemerintahan dari kedua negara tersebut selanjutnya banyak ditiru oleh negara-negara lain di dunia yang tentunya disesuaikan dengan negara yang bersangkutan.

\section{Sistem Pemerintahan Amerika Serikat}

The United State of America (U.S.A.) itu berbentuk republik berdasarkan federasi, dengan konstitusi tertulis sebagaimana ditetapkan tanggal 17 September 1787 dan muali berlaku kemudian secara efektif pada tanggal 4 Maret $1789 .{ }^{35}$

Amerika Serikat terbentuk pada tahun 1787 dan terdiri dari 50 negara bagian. Amerika Serikat merupakan sebuah negara Republik Federal yang menganut Sistem Pemerintahan Presidensiil dimana Presiden berperan sebagai badan esksekutif dan Konggres berperan sebagai badan legislatif. Sedangkan Majelis Tinggi ada di tangan Senat dan Majelis Rendah berada di tangan House of representative (DPR)

Di Amerika Serikat terdapat pemisahan kekuasaan yang tegas antara Legislatif, Eksekutif, dan Yudikatif. Pemisahaan ini terdiri dari pemisahan bagian pelaksana maupun fungsi serta kekuasaan dari badan-badan tersebut yang membatasai satu sama lain dengan menggunakan asas checks and balances yang berarti saling mengawasi untuk menjaga keseimbangan. Sedangkan keadilan ditegakkan melalui Badan Yudikatif atau Mahkamah Agung (Supreme Court) yang bebas dari pengaruh badan Legislatif dan Eksekutif serta menjamin hak-hak kebebasan dan kemerdekaan individu serta menjamin tegaknya hukum (rule of law). Amerika Serikat melakukan pemilihan Presiden 4 tahun sekali dengan menggunakan Sistem electoral votes. Dimana Presiden dan wakil Presiden dipilih dalam satu paket, seperti yang terjadi di Indonesia. Pemerintah Amerika Serikat bertugas untuk melayani rakyat karena pemerintah memperoleh kekuasaan dari rakyat.

\section{Sistem Pemerintahan Inggris}

Inggris merupakan Negara Kesatuan yang terdiri dari wilayah England, Wales, Scotland, dan Northern Ireland. Di Inggris, konvensi ketatanegaraan sangat berperan di dalam Sistem

\footnotetext{
${ }^{35}$ Sjachran Basah, Hukum Tata Negara Perbandingan, Alumni, Bandung, 1994, hlm. 54
} 
ketatanegaraannya. Inggris tidak memiliki konstitusi yang dikodifikasi padasatu naskah, tetapi menganggap berbagai aturan seperti Magna Charta (1215), Bill of Rights (1689), kebiasaaan parlemen, konvensi ketatanegaraan, serta berbagai ketentuan lainnya sebagai bagian dari konstitusi. Oleh karenanya konvensi ketatanegaraan memiliki tempat yang istimewa dalam praktik ketatanegaraan di Inggris. ${ }^{36}$

Common law merupakan sumber utama hukum Inggris. ${ }^{37}$ Karena Common law dominan dalam memperkaya materi hukumnya, maka Sistem hukum Inggris acapkali disebut Common Law Sistem. $^{38}$

Yang dimaksud dengan common law adalah adat kebiasaan yang dipraktikkan dan diterima di tengah-tengah masyarakat. Blackstone seperti dikutip Paton, membedakan adat-kebiasaan umum yang menjadi common law dari adat-kebiasaan khusus yang hanya mempengaruhi suatu kelas tertentu dan anggota-anggota dalam satu wilayah tertentu; dan telah menjadi pandangan tradisional penulis-penulis Inggris bahwa common law hanyalah adatkebiasaan umum. Ciri adat-kebiasaan khusus adalah bahwa adatkebiasaan itu terbatas pada suatu kelas tertentu atau suatu daerah tertentu karenanya, adat-kebiasaan tersebut merupakan pengecualian dari hukum Negara. Common law oleh para penulis Inggris diberi arti menurut sudut pandangnya masing-masing. ${ }^{39}$

Parlemen Inggris secara konstitusional tidak hanya terdiri dari dua kamar, sebagaimana yang ditemukan dalam berbagai tulisan ayitu majelis rendah (house of commons) dan mejelis tinggi (house of lords), ${ }^{40}$ tetapi juga Raja (Ratu). Kendati parlemen Inggris terdiri dari tiga lembaga, namun masing-masing lembaga tidak mempunyai kekuasaan sama di bidang legislatif.

Parliament is composed of three parts- the house of commons, the house of lords, and the Queen-but no part can make law on its

\footnotetext{
${ }^{36}$ Donald A. Rumokoy, op. cit., hlm. 87

${ }^{37}$ R.J. Walker, The English Legal Sistem, Butterworths, London, 1980, hlm. 3 (Dikutip dalam buku Praktik Konvensi Ketatanegaraan di Indonesia karangan Prof. Dr. Donald A. Rumokoy, SH., MH., Jakarta, Media Prima Aksara, 2011, hlm. 92)

${ }^{38}$ Lili Rasjidi, Hukum Sebagai Suatu Sistem, Remaja RosdaKarya, Bandung, 1993, hlm. 31 (Dikutip dalam buku Praktik Konvensi Ketatanegaraan di Indonesia karangan Prof. Dr. Donald A. Rumokoy, SH., MH., Jakarta, Media Prima Aksara, 2011, hlm. 92)

${ }^{39}$ Donald A. Rumokoy, op. cit., hlm. 93

${ }^{40}$ S. Pamudji, Perbandingan Pemerintahan, Bumi Aksara, Jakarta, 1994, hlm. 45 (Dikutip dalam buku Praktik Konvensi Ketatanegaraan di Indonesia karangan Prof. Dr. Donald A. Rumokoy, SH., MH., Jakarta, Media Prima Aksara, 2011, hlm. 95)
} 
own. Today the queen's function is purely formal, while the powers of the house of lords have been severely restricted. House of commons, that part of parliament elected at regular by the citizens. $^{41}$

Sistem Pemerintahan Inggris memberikan kekuasaan yang besar kepada house of commons dalam membentuk undang-undang (Act of Parliament). Raja/Ratu sebagai bagian dari parlemen hanya memiliki fungsi formal. Artinya setiap rancangan undang-undang yang dibentuk oleh house of commons wajib diajukan kepadanya dan ditandatangani. Sementara house of lords dikenakan beberapa pembatasan kewenangan dalam fungsi legislatifnya. Dengan kuatnya kedudukan parlemen, maka Sistem itu disebut parliamentary souvereignity. ${ }^{42}$

\section{Sistem Pemerintahan Malaysia}

Malaysia adalah sebuah Negara federasi yang terdiri dari tiga belas Negara bagian dan tiga wilayah persekutuan di Asia Tenggara dengan luas $329.847 \mathrm{~km}$ persegi. Ibukotanya adalah Kuala Lumpur, sedangkan putra jaya menjadi pusat Pemerintahan persekutuan. Federasi Malaysia adalah sebuah monarki konstitusional. Kepala Negara persekutuan Malaysia adalah yang dipertuan agung, biasa disebut raja Malaysia. Yang dipertuan agung dipilih dari oleh Sembilan sultan negeri-negeri Malaya, untuk menjabat selama lima tahun secara bergiliran. Empat pemimpin negeri lainnya yang bergelar Gubernur tidak turut serta dalam pemilihan.

Sistem Pemerintahan di Malaysia bermodelkan Sistem Pemerintahan Parlementer Westminster, warisan penguasa colonial Britania. Dalam praktiknya kekuasaan lebih terpusat di eksekutif daripada legislatif. Yudikatif diperlemah oleh tekanan berkelanjutan dari pemerintah selama zaman Mahathir. Kekuasaan yudikatif itu dibagikan antara pemerintah persekutuan dan pemerintah Negara bagian. Sejak kemerdekaan pada tahun 1957 Malaysia diperintah oleh koalisi multipartai yang disebut barisan nasional (pernah pula disebut aliansi).

Kekuasaan eksekutif dilaksanakan oleh kabinet yang dipimpin oleh Perdana Menteri. Kosntitusi Malaysia menetapkan bahwa Perdana Menteri haruslah anggota dewan rendah (dewan rakyat) yang

41 J. Harvey dan L. Bather, The British Constitutions and the Politics, Macmillan Education Ltd, 1984, hlm. 9, (Dikutip dalam buku Praktik Konvensi Ketatanegaraan di Indonesia karangan Prof. Dr. Donald A. Rumokoy, SH., MH., Jakarta, Media Prima Aksara, 2011, hlm. 95)

${ }^{42}$ Donald A. Rumokoy, op.cit., hlm. 96 
direstui yang dipertuan agung dan mendapat dukungan mayoritas di parlemen. Kabinet dipilih dari para anggota Dewan Rakyat dan Dewan Negara dan bertanggung jawab kepada badan itu, sedangkan kabinet merupakan anggota parlemen yang dipilih dari dewan rakyat atau dewan Negara.

Pemerintah Negara bagian dipimpin oleh Menteri besar di negerinegeri Malaya atau ketua Menteri di Negara-negara yang tidak memiliki monarki local, yakni seorang anggota majelis Negara bagian dari partai mayoritas di dalam dewan undangan negeri. Di tiap-tiap Negara bagian yang memelihara monarki local, Menteri besar haruslah seorang suku melayu muslim, meskipun penguasa ini menjadi subjek kebijaksanaan para penguasa. Kekuasaan politik di Malaysia amat penting untuk memperjuangkan suatu isu dan hak. Oleh karena kekuasaan memainkan peran yang amat penting dalam melakukan perubahan.

C. Kesimpulan

Praktik sistem pemerintahan Indonesia mengalami beberapa variasi. Pada bulan Oktober 1945 sampai sebelum Dekrit Presiden 5 Juli 1959 telah berlaku Sistem Pemerintahan Parlementer. Dimana dapat difahami bahwa dalam konstitusi Negara kita tidak dikenal Sistem tersebut namun secara praktiknya menyimpang dari amanat konstitusi. Pada masa orde baru Sistem Pemerintahan yang berlaku adalah quasi Presidensial.

Inkonsistensi penerapan Sistem Pemerintahan ini merupakan bentuk penyimpangan terhadap ketentuan UUD 1945. Keinkonsistensian penerapan Sistem Pemerintahan tersebut didasari atas konvensi ketatanegaraan dan hukum kebiasaan yang telah diterapkan sebelumnya. Disamping itu juga dapat dikatakan karena UUD 1945 sendiri memang dimaksudkan hanya sebagai revolutie -grondwet atau undang-undang dasar kilat (ucapan Bung Karno dalam sidang BPUPKI) yaitu undangundang dasar yang hanya dimaksudkan sebagai naskah konstitusi untuk sementara waktu dalam rangka persiapan Indonesia menjadi Negara yang merdeka dan berdaulat.

Setelah UUD 1945 mengalami empat kali perubahan yaitu dari tahun 1999, 2000, 2001 dan 2002 praktik Sistem Pemerintahan kita berlaku Sistem Pemerintahan Presidensial. Sistem ini menganut prinsip Separation of power (pemisahan kekuasaan) terhadap masing-masing lembaga Negara. Praktik sistem pemerintahan setelah amandemen ini belum sepenuhnya menganut sistem pemerintahan Presidensial murni dimana antara Presiden dan DPR masih memiliki hubungan yang sangat erat disamping sebagai fungsi pengawasan. 


\section{DAFTAR PUSTAKA}

Donald A. Rumokoy, Praktik Konvensi Ketatanegaraan di Indonesia - Kajian Perbandingan di Inngris, Amerika Serikat, dan Belanda, Media Prima Aksara, Jakarta, 2011

Departemen Pendidikan dan Kebudayaan, Kamus Besar Bahasa Indonesia, Balai Pustaka, Jakarta, 2002

Hartono Hadisoeprapto, Pengantar Tata Hukum Indonesia, Cet. Kelima, Liberty, Yogyakarta, 2001

Jimly Asshiddiqie, Pokok-Pokok Hukum Tata Negara Indonesia Pasca Reformasi, Cet. Kedua, PT Bhuana Ilmu Populer, Jakarta, 2008

Konstitusi dan Konstitusionalisme Indonesia, Konstitusi Press, Jakarta, 2006

J. Harvey dan L. Bather, The British Constitutions and the Politics, Macmillan Education Ltd, 1984

Lili Rasjidi, Hukum Sebagai Suatu Sistem, Remaja RosdaKarya, Bandung, 1993

Moh. Kusnardi - Harmally Ibrahim, Hukum Tata Negara Indonesia, Cet. Ketujuh, Pusat Studi Hukum Tata Negara Fakultas Hukum Universitas Indoensia dan CV Sinar Bakti, Jakarta, 1988

Moh. Mahfud, MD, Perdebatan Hukum Tata Negara Pascaamandemen Konstitusi, PT Raja Grafindo Persada, Jakarta, 2011

Ni'matul Huda, Negara Hukum, Demokrasi, dan Judicial Review, UII Press, Yogyakarta, 2005

R.J. Walker, The English Legal Sistem, Butterworths, London, 1980

Sjachran Basah, Hukum Tata Negara Perbandingan, Cet. Kelima, Alumni, Bandung, 1994

Sri Soemantri M, Bunga Rampai Hukum Tata Negara Indonesia, Alumni, Bandung, 1992

S. Pamudji, Perbandingan Pemerintahan, Bumi Aksara, Jakarta, 1994

Undang-Undang Dasar (UUD) Negara Kesatuan Republik Indonesia Tahun 1945 Undang-Undang Nomor 32 Tahun 2004 tentang Pemerintahan Daerah. 
www.slideshare.net/omcivics/pelaksanaan-Sistem-Pemerintahan-di-indonesiaericpresentation

www.google.co.id/\#sclient=psyab\&hl=id\&source $=h p \& q=$ Sistem + pemerintah $+\operatorname{Pr}$ esidensial \&pbx $=1 \&$ oq $=$ Sistem + pemerintah + Presidensial

http://panmohamadfaiz.com/2007/03/18/sistem-ketatanegaraan-indonesia-pascaamandemen/ 